\title{
Australian Journal of

\section{Nonlinear modeling proposal for the germination performance of Paspalum regnellii seeds: a species with forage potential in Brazil}

\author{
Gabriel Streck Bortolin ${ }^{1 *}$, Bruno Giacomini Sari², João Carlos Pinto Oliveira ${ }^{3}$, Maurício Marini Kopp ${ }^{3}$, \\ Rosana Tascheto Vey ${ }^{2}$, Carlos Eduardo da Silva Pedroso', Alessandro Dal'Col Lúcio Antonio Carlos \\ Ferreira da Silva²
}

\author{
${ }^{1}$ Federal University of Pelotas, CEP 96010-610, Capão do Leão, RS, Brazil \\ ${ }^{2}$ Federal University of Santa Maria, Santa Maria, RS, Brazil \\ ${ }^{3}$ Embrapa Southern Region Animal Husbandry, Bagé, RS, Brazil
}

\section{*Corresponding author: gabrielbortolin91@gmail.com}

\begin{abstract}
Finding qualified standard plants is an essential requirement in the search for high-quality pasture, fact that involves knowledge about the performance of the assessed seeds. Therefore, the aim of the present study was to evaluate the influence of seed weight on the germination behavior of Paspalum regnellii seeds through the logistic growth model. The adopted values were taken from an experiment conducted in 2016 under laboratory conditions. A pneumatic separator was used to select four seed classes, depending on the weight of one thousand seeds namely: Extra light, light, middle and weighted. The logistic model was adjusted to data about the germination rate of each class, and the parameters were compared through the $\mathrm{F}$ test. Germination rates between classes were compared based on recorded parameters and on model critical points. The logistic model adjusted well to the values and made it possible to use the parameters and critical points of the curve to describe the germination process. In addition to have low germination rate, seeds in the light-weight batch demanded longer to complete this process. Based on estimates about the parameters and the critical points of the model, the weighted-weight seeds were superior in terms of quality than seeds in the other batches, since they recorded higher germination rate in a shorter period-of-time.
\end{abstract}

Keywords: Seed quality, weight of one thousand seeds, logistic model, growth models.

Abbreviations: EL_Extra light; L_Light; M_Middle; W_Weighted; MAP_Maximum acceleration point; IP_Inflection point; MDP_ Maximum deceleration point; ADP_asymptotic deceleration point; WOTS_weight of one thousand seeds; WC_Water content.

\section{Introduction}

The genus Paspalum ranks prominent positions in almost all herbaceous communities in different ecosystems in South America. This genus, besides encompassing a large number of native forage species presenting high potential for genetic improvement due to the great intra and interspecific variability of its species, is considerably adaptable to different ecosystems. (Pereira et al., 2012; Novo et al., 2016).

The Paspalum regnellii taxon is one of the species with the potential for forage production, which was described by Mez, and cited by Coradin et al. (2011). This taxon presents perennial cycle and erect growth habit; therefore, it can reach more than $100 \mathrm{~cm}$ in free growth. According to Primavesi et al. (2008), biomass production is excellent for environment enhancement, with emphasis to soil fertility correction and to irrigation. Meirelles et al. (2013) assessed the productivity of this species and reported its favorable characteristics for animal pasture production based on its good response to intensification levels and on the minimization of negative effects of seasonality. According to Barro et al. (2012), P. regnellii records good adaptation to shaded environments and such characteristic makes the species recommended for silvipastoral systems.

The point of establishment (animal entry moment) in the pasture implantation and use processes is an important forage-cycle component. The shorter the time to establish the pasture, the greater the use of available resources. This process results in less competition with invasive species and in productivity increase during the productive period (Cunha, 2015). It is necessary to know the quality of the seeds in order to achieve a vigorous establishment, since this process depends on rapid and uniform seed emergence. However, the insufficient work involving seeds of species belonging to genus Paspalum, with emphasis to seed production, processing and quality, limits the introduction of plants with promising forage potential (Verzignassi et al., 2008). Seed selection based on weight allows removing the lighter, immature or damaged seeds, which also allows qualifying the seed batch (Melo et al., 2016a). According to Ambika et al. (2014), separating seeds into different weight classes allows the selection of more vigorous seeds, which are capable of withstanding adverse events in the field, fact that 
leads to more uniform emergences. Qualitative differences between seeds in the same batch can cause heterogeneous performance in the field in the absence of the screening process.

Growth models based on germination behaviors can be used to set the quality of different seed batches, since they are adjusted according to the sigmoidal character shown by this phenomenon. The choice for the model that best represented the growth curve was based on the quality of its adjustment to the data and on its biological interpretation of the parameters. Different types of statistical models can be adopted depending on their ability to facilitate the interpretation of processes involved in plant production. Several growth models, such as Logistico, Gompertz, Von Bertalanffy, Richards and Weibull, can be employed to model the seed (Espigolan et al., 2013). Some of these models have already been used to compare the potential of different seed batches (Gazola et al., 2011; Sousa et al., 2014); however, their use remains restricted to fit the model to the data; their interpretation is limited to model parameters.

Growth models have biological interpretation parameters capable of increasing result inferences. The asymptote can be used to determine the final germination rate. The scale parameter, which is related to the difference between the initial and asymptote observations, can be applied to describe the earliest germination start. Finally, the growth rate can be adopted to compare germination speed (Mischan et al., 2011). In addition to the parameters, the following critical points can be obtained from partial derivatives of the independent variable: maximum acceleration point (MAP), inflection point (IP), maximum deceleration point (MDP) and asymptotic deceleration point (ADP). MAP sets the moment when germination speed (acceleration) increase gets to its maximum. IP determines the moment when germination speed is in its maximum; it determines the moment when acceleration turns to deceleration. MDP sets the moment after deceleration start, when emergence speed reduction gets to its maximum. Finally, ADP determines the moment when germination increase becomes insignificant (Mischan and Pinho, 2014).

The application of the $\mathrm{F}$ test between nested models helps differentiating treatments. When it comes to seeds, the models can be adjusted to different seed batches and the behavior can be compared by using the dummy's variables. Thus, complete models, in which each batch has a specific parameter, can be compared through the $F$ test to the reduced models, whose parameters are the same (Mischan and Pinho, 2014). The model parameters can be individually compared through the same approach.

It is clear that non-linear regression models can lead to increased inference of germination results. These models may help better understanding the herein addressed phenomenon; therefore, the objective of the present study was to evaluate the use of logistic nonlinear models, as well as the biological parameters and critical points of seed germination data of four $P$. regnellii plots based on the weight of one thousand seeds.

\section{Results and Discussion}

The increased ventilation intensity led to significant differences in the weight of one thousand seeds among the four established classes (Table 1). Such outcome was expected, since it is common recording heterogeneity in the specific weight observed in evaluations focused on the quality of forage grass seeds (Silva et al, 2007; Hessel et al., 2012). According to Ambika et al. (2014), size and weight heterogeneity within a seed batch is commonly verified, since, according to the same author, these characteristics are influenced by the environment, by plant development and also by the practices adopted throughout the production cycle.

Batista and Godoy (1998) reported no homogeneity in seed quality when they evaluated the seed production and quality of 215 accessions belonging to genus Paspalum and recorded the variability of viable seeds' production. The same authors highlighted the influence of desynchronization on the flowering process.

Although there was weight differences between classes, there was no significant variation in the water content of the seeds; values close to $9 \%$ were maintained (Table 1). According to the proposition by Coimbra et al. (2009), water homogeneity content in dispersion units is essential to avoid test impairments due to the metabolic activity in the seeds. Germination values collected through the standard test allowed verifying that the logistic model was adjusted to values recorded for each of the evaluated classes. Nonlinearity, which was measured according to the methodology by Bates and Watts (1988), was lower than 1, and the normality, homogeneity and independence assumptions of the residues were observed (Table 2). This outcome shows that the estimated parameters were biased and efficient (minimum variance), as well as that the model can be used to describe the germination of $P$. regnellii seeds. The germination rate of $P$. regnellii seeds significantly changes between the evaluated classes, such changes were proportional to the seed weight increase (Figures 1 e 2). Asymptote evidenced that the weighted class presented statistically higher rates than the other classes, thus it reached $64 \%$ germination. There was reduction in the weight of one thousand seeds among the lighter seeds, which showed germination rate decrease, as observed in the middle $(57 \%)$, light $(49 \%)$ and extra light $(33 \%)$ classes (Figures 1 e 2).

The recorded values allowed verifying that the germination rate of $P$. regnellii seeds belonging to the weighted class stayed within the standards established for the commercialization of seed species belonging the genus Paspalum in Brazil. Seed batches composing the category of basic seeds of forage species belonging to genus Paspalum need to present $60 \%$ germination (minimum) in order to be commercialized, if one takes into account the normative instruction number 30, which was regulated in May 21st, 2008 (Brasil, 2008).

The herein observed difference in the germination rate of the assessed batches is often verified between seed batches that record different weights. Similar to what was observed in the current study, Hessel et al. (2012) has concluded that heavier weight Brachiaria brizanta seeds show higher germination rates due to intrinsic characteristics of this grass species, which usually presents low germination potential. Similar results were recorded by Melo et al. (2016a) when he treated Panicum maximum cv. Mombaça. According to him, the highermean weight of treated seeds allows improving the physical and physiological qualities. 
Table 1. Weight of one thousand seeds (WOTS) and water content (WC) values of Paspalum regnellii seeds fractionated in the Extra light, Light, Middle and Weighted classes.

\begin{tabular}{lcc}
\hline Classes & WOTS $(\mathrm{g})$ & WC $(\%)$ \\
\hline Extra light & $0,62 \pm 0.01 \mathrm{D}^{1}$ & $8,36 \pm 0.28 \mathrm{~A}$ \\
Light & $0,96 \pm 0.04 \mathrm{C}$ & $8,91 \pm 0.3 \mathrm{~A}$ \\
Middle & $1,03 \pm 0.02 \mathrm{~B}$ & $8,30 \pm 0.17 \mathrm{~A}$ \\
Weighted & $1,13 \pm 0.02 \mathrm{~A}$ & $9,07 \pm 0.19 \mathrm{~A}$ \\
\hline
\end{tabular}
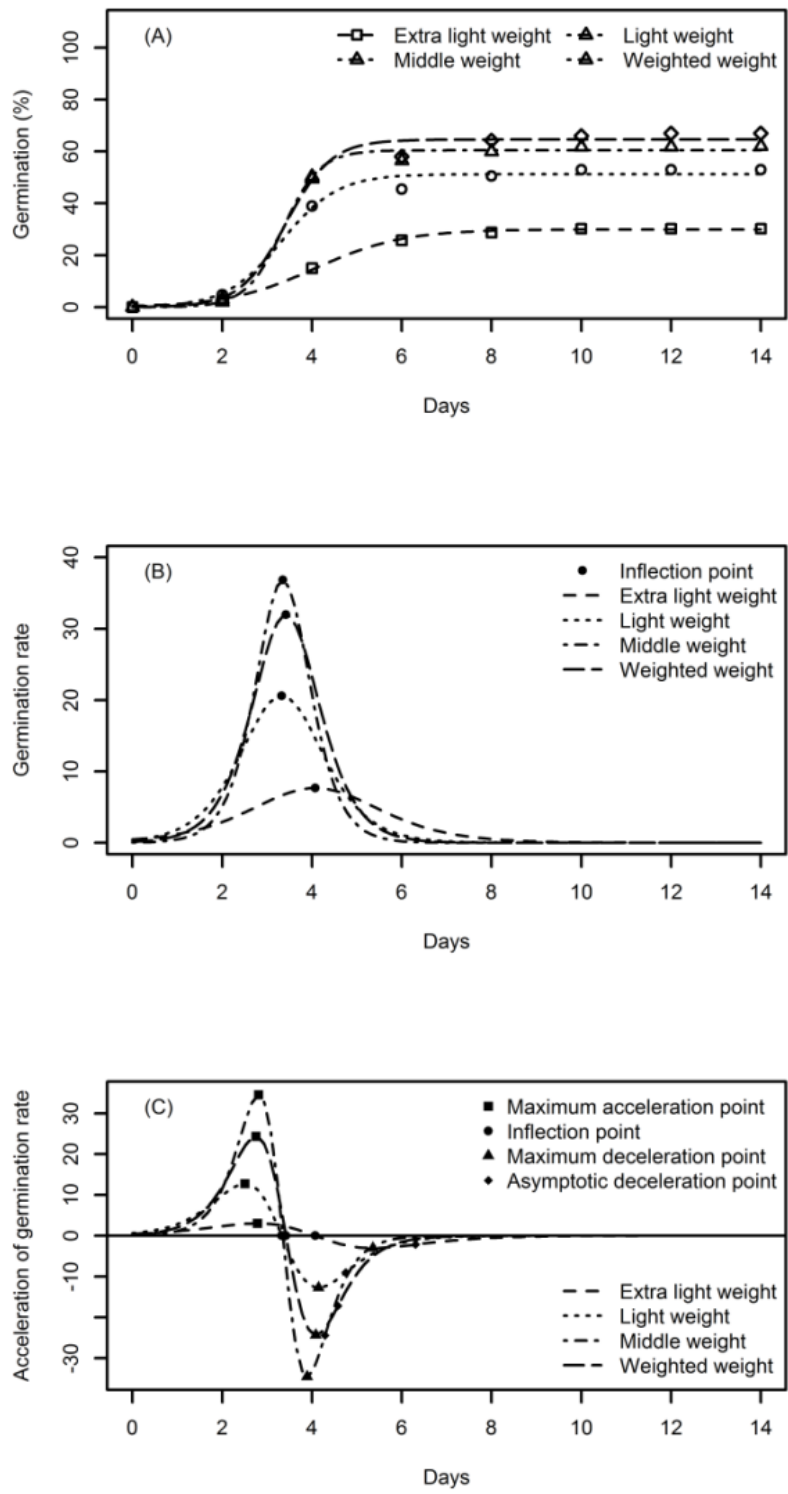

Fig 1. Adjustment of the logistic model (A), germination speed (B) and germination rate acceleration (C) adjusted for Paspalum regnellii seeds fractionated in the Extra light, Light, Middle and Weighted classes.

Table 2. $P$ values from the Shapiro Wilk normality tests, Breusch-Pagan homogeneity and Durbin Watson independence applied on the residues in Paspalum regnellii seeds fractionated in the Extra light, Light, Middle and Weighted classes.

\begin{tabular}{lccc}
\hline Classes & Shapiro Wilk & Breusch-Pagan & Durbin Watson \\
\hline Extra light & 0.06 & 0.33 & 0.66 \\
Light & 0.05 & 0.57 & 0.56 \\
Middle & 0.05 & 0.54 & 0.49 \\
Weighted & 0.05 & 0.56 & 0.58 \\
\hline
\end{tabular}




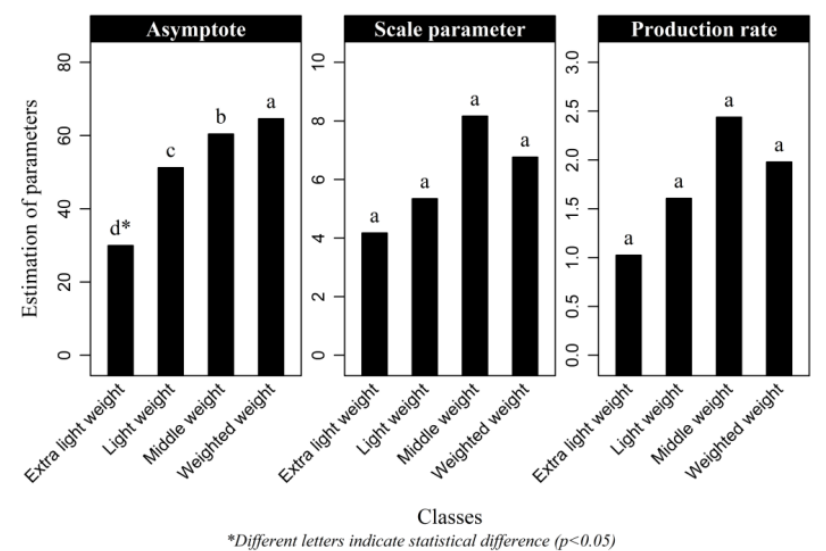

Fig 2. Comparison between the parameters of the logistic model (Asymptote, scale parameter and production rate) adjusted for Paspalum regnellii seeds fractionated in the Extra light, Light, Middle and Weighted classes.

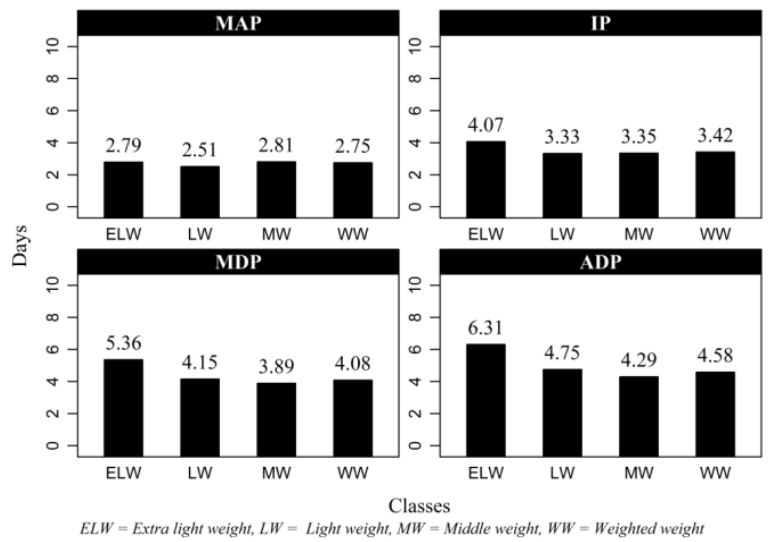

Fig 3. The abscissa values of the maximum acceleration point (MAP), inflection point (IP), maximum deceleration point (MDP), and asymptotic deceleration point (ADP) of the logistic model adjusted for Paspalum regnellii seeds fractionated in the Extra light, Light, Middle and Weighted classes.

Ambika et al. (2014) highlighted the differences in the germination potential of dispersion units; uneven weights result from high-weight seeds, which are characterized by well-formed embryos enriched with a higher reserve content than the lighter seeds. The low germination rate recorded for light $P$. regnellii seeds is in agreement with the results of the study by Mertz (2007) with cawpea seeds, in which the separation of the seeds through the gravitational table provided positive changes in the physiological and sanitary quality of the seeds. According to recent studies, contamination by pathogens can be positively correlated to seed weight. Based on Melo et al. (2017), Panicum maximum cv. "Tanzânia" seeds recording lower one thousand seeds weight show higher rate of contamination by fungus than weighted seeds. The germination process in each of the assessed classes was better characterized by the critical point (Figures 1 and 3 ). The maximum acceleration point (MAP), which characterizes the maximum speed germination increase, points towards uniformity between values recorded for the evaluated classes (approximately 2.5 days). However, values recorded at the inflection point (IP) highlight that the light, middle and weighted classes reached their maximum germination rate after 2.5 days, whereas the extra light class only reached this point at day 4 (Figure 3). The scale parameter showed the shorter exponential growth time in the light, middle and weighted classes, in comparison to the extra light class. However, the weighted seeds batch is the one with the highest germination rate among the four classes. The extra light batch had low germination rate; therefore, it required longer to reach IP, as well as to complete the germination process. Such outcome was corroborated by the production rate and by the asymptotic deceleration point (ADP) (Figures 2 and 3 ). The present results comply with the ones reported by other authors Melo (2016b), and show the importance of applying vigor tests to forage species. Faster germination speed resulting from seed weight gain was also reported by Larsen and Andreasen (2004) in his study about forage species Festuca rubra, Lolium perene and Poa pratensis. Likewise, Silva et al. (2007) concluded that the higher mean weight of Bromus seeds promoted vigor increase in comparison to lighter seeds. Maximum deceleration point values (MDP) allowed infering that lighter seeds batches lasted longer than other batches in the period when germination is significant; germination increases at day seven (Figure 2). The scale parameter showed that, although there was no statistical difference in the germination speed of the different batches, its magnitude influenced the critical point moments at seed germination (Figure 1). In addition to presenting higher germination rates, the weighted batch required shorter to complete the aforementioned step than 
batches composed of lighter seeds. The applied laboratory tests evidenced that the germination speed of a given batch is essential for vigor determination. The appropriate speed to allow the germination process to take place is linked to seed weight and size. The faster germination speed process in the batch of larger seeds is directly associated with their greater enzymatic efficiency to degrade the reserves. Mino and Inoue (1994) in hybrid vigor assessment, they found that the rapid activation of metabolic function in the embryo after water uptake is due to the heterotic F1 hybrid genotype, which is considered a key factor in the mechanism by which the heterotic F1 hybrid expresses its hybrid vigor in seed germination.

\section{Materials and Methods}

\section{Experimental data collection}

The experiment was conducted in the Laboratory of Seed Analyses of Embrapa Southern Region Animal Husbandry. Paspalum regnellii seeds of access BRA-007382 harvested in an experimental area of the same unit in Bagé, RS, Brazil, were used in the experiment. Seeds were stored in plastic containers in laboratory environment $\left(20^{\circ} \mathrm{C} \pm 3^{\circ} \mathrm{C}\right)$ for six months until the time the tests were installed. Four different classes were determined in the Deleo ${ }^{\circ}$ brand, General model, in order to assess seed weight influence. The classes were set based on the following ventilation intensities: 0.0 (extra light); 2.0 (light); 4.0 (middle) and 6.0 (weighted). Intensity values represented ventilation slot width. The following evaluations were carried out for class potential comparison and differentiation purposes: weight of one thousand seeds - determined through eight subsamples composed of 100 seeds removed from the pure portion of the seeds and individually weighed on precision scale $(0.001$ g) (Brasil, 2009). Water content was determined through the oven method at $105^{\circ} \mathrm{C} \pm 3^{\circ} \mathrm{C}$, for $24 \mathrm{~h}$. Two replicates (approximately $2 \mathrm{~g}$ each) were used in each class (Brasil, 2009). The accumulated mean germination of six replicates (50 seeds per weight class) was assessed. The seeds were placed in germinal boxes under germitest type paper moistened with water ( 2.5 times the dry-substrate mass). The boxes were placed in germinating chamber type Biological Oxygen Demand for 27 days after sowing under permanent light and constant temperature $30^{\circ} \mathrm{C}$, according to the methodology proposed by Oliveira et al. (2013) for this species. The germinated seeds were counted every two days until the end of the test. The ones recording at least 2 to $3.0 \mathrm{~mm}$ long radicles were taking into consideration (Nakagawa, 1999).

Data analysis

The logistic model was adjusted in the four seed batches:

$$
Y_{i}=\frac{\beta_{1}}{1+e^{\left(\beta_{2}-\beta_{3} t_{i}\right)}}+\varepsilon_{i} \text {, }
$$

where $Y$ was the germination value (in \%), ti was time, $\beta 1$ was the parameter representing the asymptotic value, $\beta 2$ was the parameter reflecting the distance between the initial value and asymptote, $\beta 3$ was the parameter associated with the growth rate.

The parameters were estimated based on the ordinary least squares method by using the iterative Gauss-Newton method. Subsequently, the Shapiro-Wilk, Breusch-Pagan and Durbin-Watson tests were applied to verify residue normality, homogeneity and independence, respectively (Ritz and Streibig, 2008). The quality of the adjustment done in the logistic model in each of the evaluated class was performed by checking the nonlinearity of the model based on the Bates and Watts (1998) curvature method.

Model identity tests were constructed by using the dummy's indicator variables $(\mathrm{Dj})$ to assess equity between model parameters:

$D j= \begin{cases}1, & \text { if the observation belongs the class } \mathrm{k} \\ 0, & \text { Otherwise }\end{cases}$

Wherein, $\mathrm{j}$ represented the assessed batches. The intention was to compare a complete model $(\omega)$ through this test. Such model presents different batch parameters in comparison to the reduced model $(\Omega)$, which presents common batch parameters. The complete model would be given by:

$Y_{i j}=\sum_{j=1}^{k}\left[\frac{\beta_{1 j}}{1+e^{\left(\beta_{2 j}-\beta_{3 j} t_{i}\right)}}\right]+\varepsilon_{i j}$

Where ti indicates the days; $j=1,2, \ldots, k$ indicates that the observation belongs to lot $\mathrm{k}$. It is observed that in this case, for each batch (j) there is a parameter. A reduced model would be given by:

$Y_{i j}=\sum_{j=1}^{k}\left[\frac{\beta_{1}}{1+e^{\left(\beta_{2 j}-\beta_{3 j} t_{i}\right)}}\right]+\varepsilon_{i j}$

In this case, the parameter $\beta 1$ is common to $k$ lots. The null hypothesis would be $\mathrm{HO}: \beta 11=\beta 12=\ldots=\beta 1 \mathrm{k}$. From the methodology described above, we verified whether or not null hypotheses were rejected considering a significance

$$
\begin{aligned}
& H_{0}{ }^{(1)}: \beta_{11}=\beta_{12} \\
& H_{0}^{(2)}: \beta_{11}=\beta_{13}
\end{aligned}
$$

level of $5 \%: H_{0}^{(n)}: \beta_{1(k-1)}=\beta_{1 k}$

$$
\begin{gathered}
H_{0}^{(1)}: \beta_{21}=\beta_{22} \\
H_{0}^{(2)}: \beta_{21}=\beta_{23} \\
\vdots \\
H_{0}^{(n)}: \beta_{2(k-1)}=\beta_{2 k} \\
H_{0}^{(1)}: \beta_{31}=\beta_{32} \\
H_{0}^{(2)}: \beta_{31}=\beta_{33} \\
\vdots \\
H_{0}^{(n)}: \beta_{3(k-1)}=\beta_{3 k}
\end{gathered}
$$


The comparison between the complete and reduced models was performed using the F test (Ritz and Streibig, 2008). The value of calculated $F$ was calculated by:

$F_{\text {calc }}$
$=\frac{\left[S S_{\text {Error }}(\Omega)-S S_{\text {Error }}(\omega)\right] /\left[D F_{\text {Error }}(\Omega)-D F_{\text {Error }}(\omega)\right]}{M S_{\text {Error }}(\omega)}$

The calculated $\mathrm{F}$ has distribution $\mathrm{F}$ [ $\mathrm{U}$, Degrees Freedom (DF) Error $(\omega)$ ] under $\mathrm{HO}$, where $U$ is equal to the difference between the DF Error of the complete and reduced model. Finally, the critical point coordinates resulted from partial derivatives of the independent variable. The inflection point (IP) was obtained by equating the second order derivative to zero. The maximum acceleration (MAP) and deceleration (MDP) points were obtained by zeroing the third-order derivative of the model. The asymptotic deceleration point (ADP) was obtained by equating the fourth order derivative to zero (Mischan et al., 2011). The curves of the model and the derivatives of first and second order were graphically represented in order to help interpreting the results. All analyses were carried out in the R software (R Core Team, 2014).

\section{Conclusion}

The non - linear logistic regression model allowed describing the germination of Paspalum regnellii seeds. Its parameters and critical points made it possible to increase result inferences by improving a better understanding about the germination process as seed weight function. Overall, there was direct relation between seed weight and germination rate. Weighted class seeds, besides recording higher germination rate, also presented faster speed to conclude this stage than classes composed of lighter seeds.

\section{Acknowledgements}

The first author thank the Coordenação de Aperfeiçoamento de Pessoal de Nível Superior (CAPES - Brazil)

\section{References}

Ambika S, Manonmani V, Somasundar G (2014) Review on Effect of Seed Size on Seedling Vigour and Seed Yield. Research Journal of Seed Science. 7(1): 31-38.

Bates DM, Watts D G (1998) Nonlinear regression analysis and its applications, $1^{\text {st }}$ edn. Wiley, New York. 87p.

Batista LAR, Godoy R (1998) Capacidade de produção de sementes em acessos do gênero Paspalum. Revista Brasileira de Zootecnia. 27(5): 841-847.

Brasil. Ministério da Agricultura, Pecuária e Abastecimento. Instrução Normativa Número 30, de 21 de maio de 2008. Diário Oficial da União. Brasília, 23 de maio de 2008. Seç̧ão 1, p. 45

Brasil (2009) Regras para Análise de Sementes. $1^{\text {st }}$ edn. Ministério da Agricultura, Pecuária e Abastecimento, Brasília. 396p.

Barro RS, Varella AC, Lemaire G, Medeiros RB, Saibro JC, Nabinger C, Bangel FV, Carassai IJ (2012) Forage yield and nitrogen nutrition dynamics of warm-season native forage genotypes under two shading levels and in full sunlight. Revista Brasileira de Zootecnia. 41(7): 1589-1597.
Coimbra RDA, Martins CC, Tomaz CDA, Nakagawa J (2009) Testes de vigor utilizados na avaliação da qualidade fisiológica de sementes de milho-doce (sh2). Ciência Rural. 39(9): 2402-2408.

Coradin L, Siminski A, Reis A (2011) Espécies nativas da flora brasileira de valor econômico atual ou potencial: Plantas para o futuro - Região Sul. $1^{\text {st }}$ edn. Ministério do Meio Ambiente, Brasília. 936p.

Cunha, MK (2015) Estabelecimento de pastagens cultivadas no Cerrado brasileiro: uma visão sistêmica do processo. $1^{\text {st }}$ edn. Embrapa Pesca e Aquicultura, Palmas. 62p.

Espigolan R, Baldi F, Boligon A A, Banchero G, Brito G, Manna AL, Albuquerque LGD (2013) Aplicação de modelos nãolineares para descrever a evolução de características de crescimento e carcaça em bovinos da raça Hereford. Ciência Rural. 43(3): 513-519.

Gazola S, Scapim CA, Guedes TA, de Lucca A (2011) Proposta de modelagem não-linear do desempenho germinativo de sementes de milho híbrido. Ciência Rural. 41(4): 551-556.

Hessel CLE, Villela FA, Aumonde TZ, Pedó T (2012) Mesa densimétrica e qualidade fisiológica de sementes de brachiária. Informativo ABRATES. 22(3): 73-76.

Larsen SU, Andreasen C (2004) Comparison of germination criteria in red fescue (Festuca rubra ssp. litoralis), perennial ryegrass (Lolium perenne) and Kentucky bluegrass (Poa pratensis). Seed Science and Technology. 32(2): 341-354.

Meirelles PRL, Batista LAR, Costa C, Silva MGB, Factori MA, Silveira JPF, Cavasano FA (2013) Germoplasma do gênero Paspalum com potencial para produção de forragem. Bioscience Journal. 29(5): 1587-1595.

Melo LF, Martins CC, Silva GZ, Boneti JE, Vieira RD (2016a) Beneficiamento na qualidade física e fisiológica de sementes de capim-mombaça. Revista Ciência Agronômica. 47(4): 667-664.

Melo LF, Martins CC, Silva GZ, Sanches MFG (2016b). Processing in the quality of tanzania grass seeds. Engenharia Agrícola. 36(6): 1031-1035.

Melo LF, Silva GZD, Panizzi RC, Martins CC (2017) Processing on the sanitary quality of seeds of Panicum maximum cv.'Tanzânia'. Revista Brasileira de Engenharia Agrícola e Ambiental. 21(10): 715-720.

Mertz LM, Henning FA, Maia MS, Meneghello GE, Henriques A, Madail R (2007). Qualidade fisiológica e sanitária de sementes de feijão-miúdo beneficiadas em mesa gravitacional. Revista Brasileira de Sementes, 29(3): 1-8.

Mino M, Inoue, M (1994) Analysis of glucose metabolism in the heterotic viability in seedling growth of maize F1 hybrid. Japan Journal Crop Science. 63(4): 682-688.

Mischan MM, Pinho SZ, Carvalho LR (2011) Determination of a point sufficiently close to the asymptote in nonlinear growth functions. Scientia Agricola. 68(1): 109-114.

Mischan MM, Pinho SZ (2014) Modelos não lineares: Funções assintóticas de crescimento. $1^{\text {st }}$ edn. Cultura Acadêmica, São Paulo. 183p.

Novo PE, Valls JFM, Galdeano F, Honfi Al, Espinoza F, Quarin $\mathrm{CL}$ (2016) Interspecific hybrids between Paspalum plicatulum and Paspalum oteroi: A key tool for forage breeding. Scientia Agricola. 73(4): 356-362.

Nakagawa J (1999) Testes de vigor baseados na avaliação das plântulas. In: Krzyzanowski FC, Vieira RD, França Neto JB (ed.) Vigor de sementes: Conceitos e testes. $1^{\text {st }}$ edn. ABRATES, Londrina. p.1-24. 
Oliveira JCP, Bortolin GS, Köpp MM. Metodologia para teste de germinação de Paspalum regnellii. Paper presented at the 18th Congresso Brasileiro de Sementes, Centro de Convenções Centro Sul, Florianópolis, september 16-19, 2013.

Pereira EA, Barros T, Volkmann GK, Battisti GK, Da Silva JAG, Simioni C, Dall'Agnol M (2012) Variabilidade genética de caracteres forrageiros em Paspalum. Pesquisa Agropecuária Brasileira. 47(10): 1533-1540.

Primavesi O, Primavesi AC, Batista LAR, Godoy R (2008) Adubação e produção de Paspalum em dois níveis de fertilidade de latossolo vermelho-amarelo: Estabelecimento e manutenção. Ciência e Agrotecnologia. 32(1): 242-250.

Ritz C, Streibig JC (2008). Nonlinear regression with R. Springer, New York. 148 p.
R Core Team. (2014) R: A language and environment for statistical computing. R Foundation for Statistical Computing, Vienna. $2547 \mathrm{p}$.

Silva GM, Maia MS, Moraes COC (2007) Influência do peso da semente sobre a germinação e o vigor de cevadilha vacariana (Bromus auleticus Trinius) Revista Brasileira de Agrociência. 13(1): 123-126.

Sousa IF, Kunzle Neto JE, Muniz JA, Guimarães RM, Savian TV, Muniz FR (2014) Fitting nonlinear autoregressive models to describe coffee seed germination. Ciência Rural. 44(11): 2016-2021

Verzignassi JR, Ramos AKB, Andrade CMS, Freitas EM, Lédo FJS, Godoy R, Andrade RP, Coelho SP (2008) Tecnologia de Sementes de Forrageiras Tropicais: Demandas Estratégicas de Pesquisa. Ministério da Agricultura, Pecuária e Abastecimento, Brasília. 17p. 